\title{
PSYCHICAL RESEARCH IN THE HISTORY AND PHILOSOPHY OF SCIENCE. AN INTRODUCTION AND REVIEW
}

\author{
Andreas Sommer \\ University of Cambridge \\ Churchill College \& \\ Department of History and Philosophy of Science \\ E-mail: as2399@cam.ac.uk
}

\begin{abstract}
As a prelude to articles published in this special issue, I briefly sketch changing historiographical conventions regarding the 'occult' in recent history of science and medicine scholarship. Next, a review of standard claims regarding psychical research and parapsychology in philosophical discussions of the demarcation problem reveals that these have tended to disregard basic primary sources and instead rely heavily on problematic popular accounts, simplistic notions of scientific practice, and outdated teleological historiographies of progress. I conclude by suggesting that rigorous and sensitively contextualized case studies of past elite heterodox scientists may be potentially useful to enrich historical and philosophical scholarship by highlighting epistemologies that have fallen through the crude meshes of triumphalist and postmodernist historiographical generalizations alike.
\end{abstract}

\section{Keywords}

Historiography; Psychical research; Parapsychology; Demarcation problem; Popular science 


\section{Historiographies of science and the 'occult'}

The past decades have seen an ongoing trend of historical interest in nineteenth-century mesmerism, spiritualism, psychical research and related areas western intellectuals are accustomed to view as inherently 'irrational' and 'unscientific'. While the bulk of this literature has been produced by general and cultural historians and scholars in literary, religious and gender studies, until recently there has been a notable paucity of work in these fields by historians of latenineteenth and early-twentieth century science and medicine. This was in striking contrast to the wealth of available historical scholarship exploring the intersections between science and early modern occult practices and beliefs, e.g. alchemy, astrology, Renaissance natural magic, biblical prophecy, eschatology, witchcraft and magical healing. Hence, when I sent out the call for papers for the international conference 'Psychical Research and Parapsychology in the History of Science and Medicine', held at the UCL Centre for the History of Psychological Disciplines in London on 25-27 January 2013, the main stimulus to organise such a meeting was to fathom and consolidate historical work in these areas. ${ }^{1}$ This special issue with a selection of papers presented at the conference is therefore a first concerted attempt to close a gap that has existed in history of science and medicine scholarship on the 'occult', and to stimulate further work informed by fundamental historiographical revisions that have escaped authors still adhering to simplistic science-occultism dichotomies when writing about past actors and developments deviating from present-day western standard epistemologies.

In fact, even the most conservative historian of science will now teach what previous generations ignored or denied: For instance, it is now commonly acknowledged that the revolutionary scientific works of Brahe, Kepler, Newton and other early moderns were inextricably linked to their committed beliefs in biblical prophecy, astrology and other now unorthodox ideas and practices, and are difficult to appreciate when taken out of their original context. Other 'fathers of modern science' like Francis Bacon and Robert Boyle observed preternatural goings-on and insisted that ghosts and certain instances of distant mental influence constituted facts of nature. ${ }^{2}$ During the Enlightenment it was not so much natural philosophy or medicine but the antiCatholicism of rationalistic Christianity that condemned natural magic and empirical approaches to 'things that go bump in the night' as intrinsically vulgar and laughable. While Protestant as well as irreligious Enlightenment writers ridiculed reports of apparitions and witchcraft out of intellectual

\footnotetext{
${ }^{1}$ A smaller symposium specifically addressing the links between modern psychology and psychical research was held in August 2010 at the $29^{\text {th }}$ Annual Conference of the European Society for the History of the Human Sciences, University of Utrecht, and resulted in a special issue of History of the Human Sciences, published in 2012.

${ }^{2}$ Seminal studies of early modern science and magic are, e.g., Webster (1982) and Clark (1999). On Bacon and Boyle see, fore example, Henry (2002) and Hunter (2001).
} 
discourse (thereby laying the foundations of modern anthropological theories of magic and shamanism), empirical interest in reported occult phenomena persisted as evidenced by medically and scientifically eminent proponents of Swedenborgianism, animal magnetism, romantic Naturphilosophie and related traditions. ${ }^{3}$

After modern spiritualism began to spread as a global movement in the mid-nineteenth century, the modern standard historiography of the opposition of science to magic began assuming shape steadier still when spokesmen of Christianity, agnosticism, secular humanism and philosophical materialism found themselves in rare unison by declaring proponents of spiritualism and other heterodox movements as mutual enemies. Usually from a safe distance, popularizers of fledgling scientific professions decried animal magnetism, spiritualism and related areas as 'enthusiasm', 'superstition', 'pseudo-science' and related shibboleths employed to repudiate traditions deviating from enlightened norms of belief. But not everybody was content to deride or pathologize reports of 'marvellous' events. When the Society for Psychical Research (SPR) was founded in England in 1882 to investigate certain alleged anomalous phenomena "without prejudice or prepossession of any kind, and in the same spirit of exact and unimpassioned inquiry which has enabled Science to solve so many problems, once not less obscure nor less hotly debated" ("Objects of the Society," 1882, p. 4), enlightened standard notions of the incompatibility of progressiveness and scientific interest in 'miraculous' phenomena became challenged once more. After all, it has often been observed that the Society's early list of members reads like the Who is Who of Victorian and Edwardian science, including iconic figures like Alfred Russel Wallace, William Crookes, J. J. Thomson, Oliver Lodge in Britain, Heinrich Hertz in Germany, Camille Flammarion and Marie Curie in France. ${ }^{4}$

Moreover, it was not just leading representatives of the physical sciences that made forays into some of the most hotly disputed areas of human experience. Just prior to the comparatively late emergence of professionalized psychology in Britain, leading figures within the SPR were partially successful in establishing an original English brand of psychological experimentation in the last two decades of the nineteenth century and represented British psychology at the first four International Congresses of Psychology (Le Maléfan \& Sommer, forthcoming; Rosenzweig, Holtzman, Sabourin, \& Bélanger, 2000; Sommer, 2013a, chapter 3). Merging psychological studies with

\footnotetext{
${ }^{3}$ Regarding the historicity of enlightened contempt for 'miraculous' phenomena, see Daston \& Park (1998) and Porter (1999). For revisions of stereotypical images of Romantic sciences as intrinsically irrational see, e.g., Cunningham \& Jardine (1990) and Knight (1998). For a more detailed account of fundamental historiographical repercussions of postEnlightenment wars on magical belief during the professionalization of modern psychology see Sommer (2013a).

${ }^{4}$ Important studies of the early SPR are Gauld (1968) and Williams (1984). Janet Oppenheim's standard work The Other World (1985) is copiously researched but ultimately restricted in analysis by adherence to conservative standard historiographies of the 'occult' as the absolute antithesis of 'science'.
} 
methodologically sophisticated tests of telepathy and mediumship, in collaboration with foreign psychologists English psychical researchers such as Edmund Gurney and Frederic W. H. Myers made significant conceptual, empirical and methodological contributions to the psychology of hypnotism, eyewitness testimony and hallucinations (cf. Ellenberger, 1970; Gauld, 1992; Crabtree, 1993; Alvarado, 2002; Sommer, 2013a, chapter 3). Often in collaboration with the English researchers, representatives of French psychology such as Charles Richet, Henri Beaunis and Pierre Janet conducted experiments in hypnotic telepathy (Dingwall, 1968; Plas, 2012); young psychologists formed societies and associations serving as conduits for unorthodox English and French strands of psychological experimentation in Germany (Kurzweg, 1976; Sommer, 2013b); and William James and Théodore Flournoy as the 'fathers' of professionalized psychology in the US and Switzerland adopted Frederic Myers's radical integrative research programme and sought to expand the 'new psychology' by integrating psychical research (cf. Burkhardt \& Bowers, 1986; Kelly et al., 2007; Shamdasani, 1994; Taylor, 1983, 1996; Sommer, 2013a, chapter 3).

Other pioneering psychologists particularly in Germany and the US, however, were deeply worried about politically damaging associations of the nascent psychological profession they struggled to establish with ideas and questions despised by conservative religious and irreligious intellectuals alike. Going to war against the deviant researchers, leaders of modern professionalized psychology such as Wilhelm Wundt, Wilhelm Preyer, Hugo Münsterberg, G. Stanley Hall, Joseph Jastrow, James McKeen Cattell and Edward B. Titchener lumped together naïve spiritualism and the hard-nosed empiricism of William James and other elite psychical researchers, accusing them of impeding progress by promoting dangerous superstitions. Eschewing constructive dialogues with their targets, and publishing polemical critiques in popular magazines and pamphlets, they relied on often unspecified allegations of fraud, insinuations of methodological incompetence, claims of metaphysical bias and charges of mental illness, explaining scientific interest in 'miraculous' phenomena by recourse to enlightened anthropological-pathological theories of magical belief and generalized principles of the psychology of error (Coon, 1992; Sommer, 2012b, 2013a, chapter 4; Taylor, 1996; Wolffram, 2006). ${ }^{5}$

These and related large-scale boundary disputes had a lasting impact on popular as well as scholarly historiographies of modern sciences and the 'occult', and an almost unchanged nineteenth-century Science versus superstition rhetoric still prominently figures in the public understanding and popularization of science literature in general, and the construction of the scientific image of modern psychology in particular. These historiographical artefacts continue to

\footnotetext{
${ }^{5}$ Early professional psychologists pathologizing 'occult belief' along with epistemically pluralistic elite psychical research were, e.g., Jastrow (1889, 1927), Wundt (1892, p. 110), and Hall (1910, 1918).
} 
powerfully shape academic identities and standards of what it means to be 'rational' and 'scientific', while journalistically well-connected 'Skeptic' associations for the promotion of 'Science' and 'Reason' continue to mushroom all over the world to 'protect' and 'educate' the public by aggressively debunking real and assumed charlatans and by promulgating hair-raisingly naïve teleologies of scientific progress and practice. ${ }^{6}$

All the while, intellectuals and scientists have continued to be interested in a certain class of alleged anomalous phenomena forming the subject matter of psychical research and parapsychology, ${ }^{7}$ and chairs and research groups dedicated to parapsychological (or psi) research have come and gone at universities worldwide. To date, there have been hundreds of volumes of scholarly periodicals with original empirical and conceptual contributions. To name just some of the now more readily accessible nineteenth and early-twentieth century titles, the Proceedings of the SPR (since 1884) and the American SPR (since 1885) have set the highest standards of latenineteenth and early-twentieth century scholarly discourse for psychical research. Less consistent in quality, the journals Psychische Studien, Sphinx and Zeitschrift für Parapsychologie are among the important historical titles in German language, while the Annales de sciences psychique and Revue métapsychique have been major sources of information regarding the early Francophone context.

Since World War II there has been no want of parapsychological periodicals either. The SPR and ASPR have each continued to publish their Journal and Proceedings, and in 1957 scientists interested in psi phenomena began consolidating their work within the Parapsychological Association (an affiliate of the American Association for the Advancement of Science), which issues the Journal of Parapsychology (founded in 1937 by Rhine and co-edited until his death by Harvard psychologist William McDougall) as well as the likewise peer-reviewed Proceedings of annual meetings (previously published as Research in Parapsychology). ${ }^{8}$ In addition to journals and the edited book series Advances in Parapsychological Research (nine volumes to date), there has

\footnotetext{
${ }^{6}$ I'm using the American and capitalised spelling 'Skeptics' to distinguish representatives of the ideological US-based movement from 'sceptic' as it is commonly understood in philosophical and scientific discourse, i.e. as one suspending judgement on the basis of systematically informed doubt. Closely linked to Skeptics organizations have been the creation of chairs for the 'Public Understanding of Science' at Oxford, and the recent Professorship in the 'Public Understanding of Psychology' at Hertfordshire University. For sociological studies of 'organized Skepticism' see, e.g., Pinch \& Collins (1984) and Hess (1993).

${ }^{7}$ The term 'psychical research' is traditionally associated with the investigation of alleged psychic phenomena using a variety of methods, while 'parapsychology' typically denotes their lab-based quantitative study as promoted in the 1930s by the American biologist J. B. Rhine at Duke University and later generations of researchers. For the coinage of the term 'Parapsychologie' in late-1880s Germany in the context of the professionalization of psychology see Sommer (2013b). On the academic reception of Rhine's parapsychology see the seminal study by Mauskopf \& McVaugh (1980). ${ }^{8}$ Other peer-reviewed periodicals have been the University of Edinburgh-based and now defunct European Journal of Parapsychology, the Journal of Scientific Exploration as well as the more recent Elsevier title Explore. In Germany, the Zeitschrift für Parapsychologie und Grenzgebiete der Psychologie is the main journal dedicated to psi research, while the Zeitschrift für Anomalistik (like the Journal of Scientific Exploration) covers parapsychology as one of other unorthodox fields.
} 
been a wealth of scholarly monographs, overviews, bibliographical reference works and textbooks of parapsychological research (see, for example, Driesch, 1933; Greenwood, Pratt, Rhine, Smith, \& Stuart, 1940; White \& Dale, 1973; White, 1976, 1990; Wolman, 1977; Edge, Morris, Palmer, \& Rush, 1986; Irwin \& Watt, 2007).

Whereas the most sophisticated and therefore scientifically relevant part of this literature is typically excluded from popular and educational writings on science and the 'paranormal', historical accounts routinely exclude or belittle preoccupations of many well-known scientists with controversial questions. For instance, it is not widely known that psychologists like William McDougall, Gardner Murphy and Hans Eysenck openly advocated psychical research (e.g. Sommer, 2013a, Introduction); Hans Berger's development of the electroencephalogram (EEG) was driven by what he believed was a dramatic 'crisis telepathy' experience involving his sister (Kramer, 2013; Millett, 2001); Kurt Gödel became convinced of the reality of telepathy after conducting experiments with his wife (Dawson, 1997, pp. 29-30); Wolfgang Pauli saw a link between quantum mechanics and 'poltergeist'-style mind-matter interactions he was said to have experienced (Enz, 2002; Meier, 2001); Albert Einstein expressed his conviction that telepathy "deserves the most earnest consideration, not only of the laity, but also of the psychologists by profession" (Einstein, 1962, p. ix), and even two members of the Vienna Circle, Hans Hahn (a vice president of the Austrian SPR) and Rudolf Carnap, were keenly interested in psychical research (much to the chagrin of Wittgenstein - see Carnap, 1963, p. 26; Neurath \& Cohen, 1973, p. 43). As contributions to this special issue confirm, these examples are no mere anachronisms or eccentricities, but demonstrate that serious interest in so-called psychic phenomena has endured in sometimes eminent members of scientific communities.

\section{Psychical research and the demarcation problem}

While late-nineteenth and twentieth century empirical interest in the 'miraculous', far from constituting a cultural anomaly in need of historical explanation, can be understood in terms of continuity, popular standard historiographies not only persist as the backbone for writings on the public understanding of science but have also informed professional discussions of the demarcation problem in philosophy. Though the following review is not intended as a prescriptive contribution to the philosophy of science, it will argue that here as elsewhere one can formulate a pessimistic induction: those expressing the strongest misgivings about unorthodox disciplines are typically those who made the least effort of familiarizing themselves with basic primary sources.

Perhaps the most frequent standard claim regarding psychical research is an alleged renitent metaphysical bias that has been thought to be its organizing principle and caused the typical lack of 
rigour that is supposed to have characterized this work. Mario Bunge, for example, began his analysis of parapsychology by stating that it was "the modern name for spiritualism, mediumnism, cartomancy, and other archaic beliefs and practices" (Bunge, 1967, p. 43). ${ }^{9}$ In a later article, Bunge further complained that parapsychological researchers were "more attracted to the supernatural than to the material, and to the arcane than to what can be explained. No wonder, for they are spiritualists not materialists" (Bunge, 1991, p. 135). Similarly, for Paul Churchland (1998) the history of parapsychology reduces to that of a collective attempt of finding "some unpatchable hole in materialism" (p. 319), and in his contribution to an Aristotelian Society symposium on psychical research, philosopher Robert Robinson maintained the discipline's history "has told us nothing about man's nature except that he likes mysteries and likes to believe in spirits and wants to go on living” (Robinson, 1950, p. 205).

Historians (as well as many present-day scientists) will find Bunge's insistence on a materialistic world-view as a necessary condition of scientificity odd not least since this criterion would remove large sectors of iconic figures ranging from Bacon to Planck from the scientific halls of fame. Moreover, relevant primary sources quickly reveal that elite psychical researchers were driven by a variety of concerns and held often conflicting epistemological presuppositions, ranging from desires to establish evidence-based foundations for undogmatic and humanistic forms of spirituality to positivist-inductivist approaches indifferent and even utterly unsympathetic to religious questions (Sommer, 2013a, chapter 2). Not only the Vienna Circle example enormously complicates assertions of metaphysical bias. The doyen of French psychical research, Nobel laureate Charles Richet, for instance, categorically rejected the 'spirit hypothesis' to account for mediumistic phenomena, and being a materialist perhaps as absolute as Bunge and Churchland, he was confident that sooner or later explanations compatible with his materialist convictions would come forth for telepathy, clairvoyance and other controversial phenomena of whose existence he became fully convinced (cf. Richet, 1923, 1924). Other 'anomalistic inductivist' psychical researchers like the Munich physician and sexologist Albert von Schrenck-Notzing, the philosopher-psychologist Julian Ochorowicz (a leader of Polish positivism and original instigator of the International Congress of Psychology) and the Italian psychologist Enrico Morselli (see Maria Teresa Brancaccio's essay in this volume) had absolutely no interests in promoting religious tenets through their investigations of mediums either, and like Richet they were decidedly hostile to the 'spirit hypothesis'. There was never a time when the community of parapsychological researchers was dominated by spiritualist or metaphysical dogma, and some prominent parapsychologists

\footnotetext{
${ }^{9}$ Philosopher Nicholas Maxwell likewise thought that parapsychology belonged to the "the most bizarre and absurd of pseudoscientific, quasi-religious disciplines one cares to think of” (Maxwell, 1974, p. 249).
} 
continue to hold squarely epiphenomalist and materialist positions today. ${ }^{10}$

Moreover, the history of psychical research and its repudiation from the territories of mainstream science is not simply one of 'science' (let alone 'scientific materialism') versus 'superstition' as popular standard claims would have it. In fact, whereas today political assaults on parapsychology are typically spearheaded by well-connected popularizers of secular humanism and militant atheism, among the most outspoken opponents of nineteenth-century psychical research were men of science and letters with strong religious convictions. Michael Faraday (who would nowadays qualify as a 'creationist' and who considered spiritualism a blasphemy), for example, accepted an invitation to investigate the medium D. D. Home, but only the condition that Home were to admit, should Faraday corroborate any anomalous effects, "the utterly contemptible character of them" (Tyndall, 1868, p. 6, cited in Lamont, 2005, p. 132). Hardly surprising, Home did not accept Faraday's caveat, and yet enlightened journalists quickly began to spread the word that the medium had evaded investigation by the great scientist. ${ }^{11}$ Shannon Delorme's contribution to this special issue on the Unitarian physiologist and vocal public opponent of Alfred R. Wallace, William Crookes and other scientists investigating spiritualism, William B. Carpenter, likewise shows that popular claims of the refutation of certain unorthodox traditions and beliefs having occurred through 'science' (i.e. by careful and dispassionate empirical testing) need to be soundly qualified.

Another standard objection to psychical research is that its supposed effects are notoriously capricious and unreplicable. Mario Bunge, for whom the history of parapsychology merely boils down to a continued "conspiracy" of scientific dilettantes (Bunge, 1967, p. 45), observed that psychic phenomena "are not repeatable, at least in the presence of unbelievers" (p. 44). Similarly, Antony Flew agreed that "If scientific-minded people view the evidence of psychical research with suspicion because it is not repeatable, then they are quite right. The whole object of the scientific exercise is to discover true laws, and theories that explain the truth of these laws (Flew, 1978, p. 268). As Richard Noakes' contribution to this volume strikingly shows, however, it is not only since Michael Polanyi (1962) discussed essentially tacit factors in the measurement and replication of effects even in conventional science that simplistic concepts of experimental replicability have been

\footnotetext{
${ }^{10}$ For example, the current president of the SPR, psychologist Richard Broughton, and the lead investigator of the famous CIA 'Stargate' project, physicist Edwin May (a disciple of Daniel Dennett), are among those categorically rejecting any transcendental, religious or spiritual implications of parapsychology. For a survey of epistemological positions within the community of parapsychological researchers, see Blackmore (1989). On the question of epistemic pluralism in parapsychology see also Hövelmann (1987).

${ }^{11}$ Some decades later, psychologists ruthlessly guarding the territories of their nascent profession routinely emphasised the supposed dangers of unrestrictedly empirical approaches to spiritualism and telepathy for enlightened Christianity (Sommer, 2013a, chapters 1 \& 4).
} 
subjected to more subtle analysis. ${ }^{12}$

Moreover, though a consultation of some of the primary literature cited above will quickly reveal a lack of consensus which if any of the psychic phenomena have been established beyond doubt within the parapsychological community, ${ }^{13}$ even unsympathetic external observers have occasionally expressed the opinion that the replication rate in parapsychology was remarkable and the evidence therefore conclusive. Alan Turing, for example, commented on the accumulated experimental data: "How we should like to discredit them! Unfortunately the statistical evidence, at least for telepathy, is overwhelming" (Turing, 1950, p. 453). Likewise, mathematician George Spencer-Brown admitted that he could not fault the typical methodological rigour and validity of parapsychological experimentation and - convinced psi phenomena were absolutely impossible found the accumulating data so robust that instead of employing popular standard responses such as fraud or methodological incompetence concluded that Rhine and colleagues had provided "the most prominent empirical reason for beginning to doubt the universal applicability of classical frequency probability" (Spencer-Brown, 1957, p. 247). Among philosophers of science, Michael Scriven has expressed similarly reaffirming opinions regarding the robustness of parapsychological effects. Juxtaposing psychoanalysis and parapsychology, he believed that "psychoanalysis provides us with a great theory without a factual foundation; parapsychology, a factual basis on which there is yet to be built a great theory" (Scriven, 1964, p. 104). ${ }^{14}$

When Francis Bacon proposed experiments to test fascinatio (an early modern equivalent of psi) he noted: "It is true, that that may hold in these things which is the general Root of Superstition; namely, that men observe when things hit, and not when they miss, and commit to Memory the one, and forget and pass over the other" (Bacon, 1670, p. 212). But he also cautioned that "Men are to admonished, that they do not withdraw credit from the Operations by Transmission of Spirits and Force of Imagination, because the effects fail sometimes" (ibid., p. 198). Long before

\footnotetext{
${ }^{12}$ The often fickle behaviour and capriciousness of instruments in the physical sciences is rarely addressed in popular chronologies of scientific progress, which critics of unorthodox sciences are so fond of promulgating. For example, when Robert Boyle launched his experimental programme, it galled him that contemporaries were often unable to replicate his experiments with the air pump (Shapin \& Schaffer, 1985, chapter 6), and works such as Harry Collins's seminal study of the sociology of replication in mainstream science as well as in parapsychology (Collins, 1992) still have done little to help inform popular as well as scholarly accounts of replication of controversial phenomena.

${ }^{13}$ See, however, Utts (1991).

${ }^{14}$ Similarly, Paul Churchland believes that to "a philosopher or historian of science, parapsychology appears as a strikingly atheoretical discipline" (Churchland, 1998, p. 312, original italics). While Scriven at least demonstrates intimate familiarity with the work of the relatively atheoretical Rhine and colleagues, Churchland seems completely unaware of both the historical and contemporary wealth of theory-driven parapsychological research. We remember that Frederic Myers's theoretical framework of the 'subliminal self', for example, was partially adopted by James, Flournoy, Jung and other eminent psychologists. After it became eclipsed by psychoanalysis, Jungian analytical psychology and other depth psychologies, there has never been a lack of more traditionally 'naturalistic' theories. For a thorough reevaluation of Myers's theoretical framework, see Kelly et al. (2007). Overviews of theories in experimental parapsychology are Rao (1978) and Stokes (1987). More recent theoretical proposals are, e.g., Atmanspacher, Römer, \& Walach (2002) and Carpenter (2012).
} 
psychologists began studying the role of experimenter effects as a methodological problem in conventional as well as unorthodox science, psychical researchers like Edmund Gurney argued:

The man who first hears of thought-transference very naturally imagines that, if it is a reality, it ought to be demonstrated to him at a moment's notice. He forgets that the experiment being essentially a mental one, his own presence [...] may be a factor in it; that he is demanding that a delicate weighing operation shall be carried out, while he himself, a person of unknown weight, sits judicially in one of the scales. After a time he will learn to allow for the conditions of his instruments, and will not expect in the operations of an obscure vital influence the rigorous certainty of a chemical reaction (Gurney, Myers, \& Podmore, 1886, vol. 1, p. 51).

Whereas there has never been a shortage of dubious psychic claimants avoiding tests by maintaining that any degree of critical attitude had detrimental effects on their performances, the standard sceptical literature shows a remarkable lack of interest to distinguish between obvious selfimmunization strategies and observations by critical and experienced investigators with flawless scientific and clinical reputations and credentials. ${ }^{15}$ Instead, often on the backdrop of simplistic notions of replicability, critics have interpreted statements such as Gurney's as clear-cut evidence for cover-ups of fraud the investigated subjects must have committed. ${ }^{16}$ Moreover, some of the hard-liners whose writings have informed the modern 'enlightened' standard discourse on psychic phenomena such as Joseph Jastrow, G. Stanley Hall, Hugo Münsterberg, Albert Moll, and today the secular messiah of the Skeptics movement, magician and professional debunker James Randi, have displayed attitudes and behaviours in their widely publicised 'investigations' of psychic claimants strongly reminiscent of the proverbial Great Inquisitor. One does not have to be a psychologist let alone an advocate of psychical research to acknowledge that the performance of subjects even in

\footnotetext{
${ }^{15}$ For interesting statements relevant to the problems of replicability and fraud in mediumship research, see, e.g., Ochorowicz (1896), Hodgson (1900), and Bleuler (1930). See also Paul Feyerabend's reference to mediums as instruments in his reply to Bunge (Feyerabend, 1991, p. 183).

${ }^{16}$ While this is not the place to discuss and weigh the concrete historical evidence for fraud in psychical research, there is a telling asymmetry in standard claims of fraud as one of the discipline's defining features. But as philosopher Curt Ducasse cautioned, "allegations of detection of fraud [...] have to be scrutinized as closely and as critically as must the testimony for the reality of the phenomena. For there is likely to be just as much wishful thinking, prejudice, emotion, snap judgement, naivité, and intellectual dishonesty on the side of orthodoxy [...] as on the side of hunger for and of belief in the marvellous" (Ducasse, 1958, p. 22). Likewise, William James observed "The 'scientist,' who is confident of 'fraud' here, must remember that in science as much as in common life an hypothesis must receive some positive specification and determination before it can be profitably discussed; and a fraud which is no assigned kind of fraud, but simply 'fraud' at large, fraud in abstracto, can hardly be regarded as a specially scientific explanation of specific concrete facts" (James, 1898, p. 421), an argument later developed by Pinch (1979). Yet it is customary in the popular science as well as professional philosophy literature on demarcation to equate claims of fraud in marginalized disciplines with evidence for fraud, usually tacitly implying that mainstream science was completely unimpinged by data manipulation. Philosophical advocates of psychical research like Stephen Braude (1997) have therefore opposed to the standard procedure of reducing the history of parapsychological research to undisputed instances of detected fraud without attempting to proportion those with the strongest cases and data.
} 
humdrum psychology experiments will usually be affected if investigators don’t even try to conceal their hostility towards them. ${ }^{17}$

Another historical consideration complicates sweeping assurances that 'science' has been unable to confirm alleged parapsychological effects. In order for an effect claimed by one investigator to be confirmed by another, naturally the other must be willing to test in the first place. But it's not only since Thomas Kuhn's observations that historians, philosophers and not least men and women of science themselves began to acknowledge that scientists have been notoriously bad at keeping an open mind regarding new ideas. Add to this general observation specific and local instances where external conditions were hardly conducive to an unrestricted empiricism regarding the 'occult' - Bismarck's Kulturkampf, for example, when 'superstition' and 'irrationality' were used as powerful rhetorical devices in the war against Catholic politics during the professionalization of psychology and other scientific disciplines in Germany -, and it is hardly surprising that professional scientists have tended to flatly refuse opportunities of testing the occurrence of 'marvellous' phenomena. ${ }^{18}$ Chantal Marazzia and Fabio de Sio's article in this special issue on parapsychological research involving animals in early twentieth-century Germany, for example, shows that the Kulturkampf continued to reverberate in German academic culture long after Bismarck, and there are many other cases in other countries where the question of the 'occult' had a broadly political impact on the formation of psychology and other modern scientific professions. The 'enlightened imperative' to do away with any supposedly irrational elements also guided the medical normalization of animal magnetism into modern hypnotism (cf. Gauld, 1992; Winter, 1998), and as Andrea Graus's essay in this volume implies, the Spanish case formed no exception.

Regarding concrete instances of refusals to investigate, Lorraine Daston and Katharine Park observed that William James as the 'father' of American psychology “thought science would be renewed by more attention to the 'dust-cloud of exceptional observations,' but his colleagues regarded his own investigations of spiritualism with skepticism and mockery" (Daston \& Park,

\footnotetext{
${ }^{17}$ On Jastrow, Hall and Münsterberg, see Blum (2007), Taylor (1996) and Sommer (2012b, 2013a, chapter 4). For Albert Moll's combat against 'superstition' see Sommer (2012a) and Wolffram (2006). Unsavoury encounters with the 'Amazing Randi', whose lucrative bullying of deviant scientists and their subjects has earned him awards by the American Physical Society and the MacArthur Foundation, have been documented not only by his targets but also by sociologists like Harry Collins and Trevor Pinch (cf. Collins, 1983; Collins \& Pinch, 1982). Regarding the support of Randi by prominent scientists, Harry Collins and Robert Evans protested that "it is hard to remain neutral in the face of the process; we find ourselves wanting to be prescriptive and say that this is 'wrong' - it is a dereliction of scientific duty. After all, among other things, scientists are there to help us know whether there are paranormal effects or homeopathic effects, but their input should be based on their best scientific efforts; ex-cathedra statements, or dirty tricks, are of no special value, nor should scientists pass their responsibility to outside groups" (Collins \& Evans, 2002, p. 265).

${ }^{18}$ On the Kulturkampf ('Struggle for culture') and its political and historiographical implications, see, e.g. Blackbourn (1993) and Sommer (2013a, chapters $1 \& 4)$.
} 
1998, p. 367). But upon closer inspection this 'scepticism' was programmatic rather than informed. James's writings and letters are replete with complaints about ex cathedra dismissals of his investigations by scientific and philosophical colleagues who had refused to see for themselves if James was a dupe or not. When trying to recruit colleagues to privately join him test the reported psychic capacities of the Boston medium Leonora Piper, for example, most simply declined, and at least two of them - Hugo Münsterberg and Josiah Royce - nevertheless continued to publicly attack and misrepresent the published work by elite psychical researchers such as James and his friends Gurney, Richard Hodgson and F.W.H. Myers (cf. James, 1901, p. 15; Sommer, 2012b, pp. 29-31, 38n15). In a letter to James McKeen Cattell, James therefore confessed "I used to think the story of the peripatetic astronomers who wouldn't look through Galileo's telescope at Jupiter's moons (preferring aloofness coupled with authoritativeness) was a fable, but the complexion of the time gives it proof'. 19

Modern philosophers adopting either of the popular standard claims regarding psychical research and other stereotypical 'pseudo-sciences' - metaphysical bias, gullibility, fraud, methodological incompetence, lack of replicability, and theoretical poverty - such as Rogosin (1938), Robinson (1950), Kneale (1950), Mundle (1950), Bunge (e.g. 1967, 1984, 1991), Flew (1978, 1987), Toulmin (1986), Lugg (1987), Bogen \& Woodward (1988), Hacking (1988, 1993), Churchland (1998), Mahner (2007), and Pigliucci \& Boudry (2013) have shown very little regard for historical detail and context. Essentially relying on highly problematic secondary sources and counting unsuccessful replications published in mainstream science journals only, philosophers dismissing psychical research as pseudo- or non-science as a rule promulgate the kind of misleading images of scientific practice typically found in productions of the popular science industry. ${ }^{20}$ Professional discussions of the demarcation problem by philosophers are strongly dominated by what self-appointed popular guardians of 'Science' and 'Reason' claim 'the parapsychologists' do, rather than by what these and other heterodox scientists actually have been doing as far as this is possible to reconstruct through original publications, archival material and other standard primary

\footnotetext{
${ }^{19}$ W. James to J. McKeen Cattell, 10 January 1899, in Skrupskelis \& Berkeley (1992-2004, vol. 8, p. 483). Further historical instances of 'aloofness coupled with authoritativeness' in the response to psychical research by professional scientists were documented by Prince (1930).

${ }^{20}$ The scholarly primary literature of parapsychology and psychical research mentioned above is usually ignored and substituted by references to popular magazines like the Skeptical Inquirer (the 'Magazine for Science and Reason'), published by the international flagship of the 'Skeptics' movement, the 'Committee of Skeptical Investigation' (CSI, previously the 'Committee for the Scientific Investigation of Claims of the Paranormal'), monographs typically produced by Prometheus Press (a publishing house owned by a founder of the modern Skeptics movement, the recently deceased militant secular humanist philosopher Paul Kurtz (Berkley, 1987), and, not least, writings by problematic historical debunkers like Jastrow, Hall and Münsterberg. The usually deeply biased entries on parapsychological topics on Wikipedia are also dominated by the literature produced by modern Enlightenment crusaders organised in Skeptics clubs and associations.
} 
sources of historical research.

\section{Conclusion: What does it mean to be rational?}

From about the late 1970s, discussions of demarcation have started shifting from philosophy to sociology and history of science, and sociological studies of public and political responses to parapsychological research suggest that very little has changed in its popular and academic reception. ${ }^{21}$ Whilst critics continue to launch uninformed but widely publicised attacks, editors of mainstream journals have admitted to stick to the rule of rejecting papers reporting positive psi effects irrespective of the quality of submitted manuscripts. And whereas it is still almost impossible for scientists to get negative replication studies in comparatively uncontroversial areas published, reports of unsuccessful psi experiments have become convenient ways of promoting one's career particularly in psychology, where manuscripts confirming the parapsychological null hypothesis continue to help bolster psychology's 'scientific' image. All the while, a flood of studies in the psychology of paranormal belief and 'anomalistic psychology' disregard relevant empirical data from psychical research, feature Joseph Jastrow, James Randi and other hard-liners as patron saints, and subtly perpetuate the enlightened pathologization of deviant epistemologies by explaining them through a whole battery of generalized biases and cognitive or emotional deficiencies. $^{22}$

As voices from the precognition survey by the writer Joseph Priestley in 1960s Britain (studied in Katy Price's contribution to this special issue) appear to confirm, the normalization of the exceptional has come at the heavy prize of social stigmatisation. Regardless of social and intellectual status, most of us simply do not want to be associated with fields of research whose subject matter public opinion has equated with quackery, folly, theological corruption, intellectual vulgarity and mental illness. Having grown up learning that the belief in the very possibility of the occurrence of certain hypothetical phenomena anachronistically labelled as 'supernatural',23 constitutes the absolute opposite of a 'scientific' and 'rational' attitude, we are hardly ever

\footnotetext{
${ }^{21}$ For sociological and historical studies of demarcation, see, for example, Mauskopf (1979), Wallis (1979), Gieryn (1983), Rupnow, Lipphardt, Thiel, \& Wesseley (2008). Sociological investigations of parapsychology are, e.g., Collins \& Pinch (1979, 1982), Hess (1992, 1993), McClenon (1984).

${ }^{22}$ See the standard textbook of 'anomalistic psychology' (Zusne \& Jones, 1989) and activities by members of the Anomalistic Psychology Research Unit at Goldsmiths University, London, who also publish a popular 'Skeptic' magazine. More differentiating and scrupulously informed works on clinical and empirical aspects of exceptional human experiences like Cardeña, Lynn, \& Krippner (2000) still form the exception in discussions of the psychology of 'paranormal belief'.

${ }^{23}$ While Richard Noakes has shown that elite Victorian physical scientists investigating spiritualism and related problems fundamentally challenged traditional naturalism-supernaturalism dichotomies (e.g. Noakes, 2004a, 2004b, 2008), I made a similar case in my reconstruction of debates around psychical research in the human sciences, notably during the formation of modern professionalized psychology (Sommer, 2013a).
} 
encouraged to investigate the historicity of modern standard attitudes dismissive of the subject matter of psychical research. It can therefore be safely assumed that these cultural and social constraints have coerced many to keep their unorthodox convictions to themselves. A possible case in question might be Karl Popper, who wrote to Ivor Grattan-Guinness in 1984 regarding parapsychological phenomena: "I feel confident that such things exist, but the attempt to make them 'scientific' seems to me not only unsuccessful so far, but to lead to a travesty" (Grattan-Guinness, 1998, p. 470). Many readers might be surprised to hear that Popper was convinced that psychic phenomena occur, and Popper's request to the recipient of his letter of treating this admission confidentially (Grattan-Guinness thought it justified to disregard the request after Popper's death) might be interpreted in the above sense. ${ }^{24}$

The stigma of deviant beliefs has also created severe methodological problems for historians. ${ }^{25}$ Though triumphalist and great scientist histories are no longer in vogue for good reasons, a downside of postmodern historians' anxious avoidance of producing hagiographies is an almost complete neglect to identify and integrate into analysis certain casualties of crude historiographical conventions and generalizations. I assume, for example, that most readers will never have heard of the main protagonist of Marazzia and de Sio's essay in this volume, Karl Krall. Critical but sympathetic and thoroughly contextualized reconstructions of works and concerns of other historical figures whose dedication to unorthodox scientific questions have resulted in their practical invisibility in official histories regardless of their high intellectual calibre and integrity possible candidates might include Alice Johnson and Whately Carington in Britain, Gerda Walther and Fritz Grunewald in Germany, and Walter Franklin Prince and Rhea White in the US - may enrich historical and philosophical scholarship by providing a fine-grained picture of sensibilities and epistemological positions that appear to have become scarce today. Not least, like Ian Kidd's article in this volume, such studies might remind us that a cultivation of basic intellectual virtues (such as humility in the face of evidence contradicting prior beliefs, and courage in defending new discoveries even at personal risk) is necessary for the scientific enterprise to maintain its popular appeal as an intrinsically progressive endeavour.

\footnotetext{
${ }^{24}$ As a note to the history of falsificationism, it is curious that both William James and Popper used anomalous colouration in birds to illustrate refuting instances. James announced that for him a decade of first-hand tests of the trance phenomena of Leonora Piper had falsified the great induction of psychology, nihil est in intellectu quod non prius fuerit in sensu: "If you will let me use the language of the professional logic shop, a universal proposition can be made untrue by a particular instance. If you wish to upset the law that all crows are black, you mustn't seek to show that no crows are; it is enough if you prove one single crow to be white. My own white crow is Mrs. Piper" (James, 1896, p. 884). Popper's subsequent choice of a black swan as a falsifying instance is peculiar enough, though it is probably idle to speculate whether he was familiar with James's statement.

${ }^{25}$ I reserve a comprehensive discussion of fundamental methodological difficulties raised by historians' safe but stagnant reliance on problematic secondary sources on the 'occult' for a separate occasion.
} 
Lastly, it might be evident that historians addressing certain asymmetries firmly ingrained in western academic culture and thinking styles face the risk of becoming intellectual outlaws themselves. To attempt facilitating balanced and informed discussion of forever disputed areas of human experience like those that have formed the subject matter of psychical research requires cutting through a rather thorny thicket of unhelpful myths of scientific epistemologies and practice, whose deep roots have vanished from public awareness. Hence, even though it should be clear that as historians it can hardly be our job to resolve age-old scientific controversies let alone make claims regarding the existence or non-existence of psychic phenomena, just by pointing out glaring asymmetries in the standard discourse about psychical research there is a genuine danger of attracting the ire of certain influential groups and figures who have been quick to level charges of 'relativism' and even 'anti-science'. Aware that the topics treated in this special issue thoroughly go against the grain of many ideologies and epistemological standard positions, its contributors strove to employ those core principles that most will agree make good science as well as good history: contextualised evidence and differentiated analysis.

\section{Acknowledgements}

I am immensely grateful to Greg Radick, who has enthusiastically supported the project of a special issue on psychical research from its commencement. Research for this essay was funded by a Wellcome Trust medical humanities doctoral studentship. Cedar Creek Institute, Charlottesville, VA, and the Perrott-Warrick Fund at Trinity College, Cambridge, have kindly supported the writing up of this article. My thanks go also to all authors who contributed to this special issue, as well as to Carlos Alvarado, Mary Rose Barrington, Graeme Gooday, Matei Iagher, Jeff Kripal, Sarah Marks, Leslie Price, Sonu Shamdasani and Roger Smith, who kindly acted as referees.

\section{References}

Alvarado, C. S. (2002). Dissociation in Britain during the late nineteenth century: The Society for Psychical Research, 1882-1900. Journal of Trauma \& Dissociation, 3, 9-33.

Atmanspacher, H., Römer, H., \& Walach, H. (2002). Weak quantum theory: complementarity and entanglement in physics and beyond. Foundations of Physics, 32, 379-406.

Bacon, F. (1670). Sylva Sylvarum, or A Natural History, in Ten Centuries (ninth ed.). London: William Lee.

Berkley, M. (1987). Prometheus unbound: A skeptical man with a mission runs a skeptical publishing house. Publishers Weekly, 231 (January 16), 32-34. 
Blackbourn, D. (1993). Marpingen: Apparitions of the Virgin Mary in Bismarckian Germany.

Oxford: Oxford University Press.

Blackmore, S. (1989). What do we really think? A survey of parapsychologists and skeptics. Journal of the Society for Psychical Research, 55, 251-262.

Bleuler, E. (1930). Vom Okkultismus und seinen Kritiken. Zeitschrift für Parapsychologie, 5, 654680.

Blum, D. (2007). Ghost Hunters. William James and the Search for Scientific Proof of Life After Death. London: Century.

Bogen, J., \& Woodward, J. (1988). Saving the phenomena. The Philosophical Review, 97, 303-352.

Braude, S. E. (1997). The Limits of Influence. Psychokinesis and the Philosophy of Science (revised ed.). Lanham, MD: University Press of America.

Bunge, M. A. (1967). Philosophy of Science: From Problem to Theory. Berlin: Springer.

Bunge, M. A. (1984). What is pseudoscience? Skeptical Inquirer, 9, 36-42.

Bunge, M. A. (1991). A skeptic's beliefs and disbeliefs. New Ideas in Psychology, 9, 131-149.

Burkhardt, F. H., \& Bowers, F. (Eds.). (1986). Essays in Psychical Research (The Works of William James). Cambridge, MA: Harvard University Press.

Cardeña, E., Lynn, S. J., \& Krippner, S. (Eds.). (2000). Varieties of Anomalous Experience: Examining the Scientific Evidence. Washington, D. C.: American Psychological Association. Carnap, R. (1963). Intellectual autobiography. In A. Schilpp (Ed.), The Philosophy of Rudolf Carnap (pp. 3-84). La Salle: Open Court.

Carpenter, J. C. (2012). First Sight. ESP and Parapsychology in Everyday Life. Lanham, MD: Rowman \& Littlefield.

Churchland, P. M. (1998). How parapsychology could become a science. In P. M. Churchland \& P. S. Churchland (Eds.), On the Contrary. Critical Essays, 1987-1997 (pp. 305-319). Cambridge, MA: MIT Press.

Clark, S. (1999). Thinking with Demons: The Idea of Witchcraft in Early Modern Europe. Oxford: Oxford University Press.

Collins, H. M. (1983). Magicians in the laboratory: A new role to play. New Scientist, 98 (30 June), 929-931.

Collins, H. M. (1992). Changing Order: Replication and Induction in Scientific Practice. London: Sage.

Collins, H. M., \& Evans, R. (2002). The third wave of science studies: Studies of expertise and experience. Social Studies of Science, 32, 235-296.

Collins, H. M., \& Pinch, T. J. (1979). The construction of the paranormal: nothing unscientific is 
happening. In R. Wallis (Ed.), On the Margins of Science: The Social Construction of Rejected Knowledge (Sociological Review Monograph, vol. 27) (pp. 237-270). Keele: University of Keele.

Collins, H. M., \& Pinch, T. J. (1982). Frames of Meaning: The Social Construction of Extraordinary Science. London: Routledge \& Kegan Paul.

Coon, D. J. (1992). Testing the limits of sense and science. American experimental psychologists combat spiritualism. American Psychologist, 47, 143-151.

Crabtree, A. (1993). From Mesmer to Freud. Magnetic Sleep and the Roots of Psychological Healing. New Haven, CT: Yale University Press.

Cunningham, A., \& Jardine, N. (Eds.). (1990). Romanticism and the Sciences. Cambridge: Cambridge University Press.

Daston, L., \& Park, K. (1998). Wonders and the Order of Nature, 1150-1750. New York: Zone Books.

Dawson, J. W. (1997). Logical Dilemmas: The Life and Work of Kurt Gödel. Wellesley, MA: A.K. Peters.

Dingwall, E. J. (1968). Abnormal Hypnotic Phenomena. Volume I. Hypnotism in France, 18001900. London: J. \& A. Churchill.

Driesch, H. (1933). Psychical Research. The Science of the Super-Normal (T. Besterman, Trans.). London: G. Bell \& Sons.

Ducasse, C. J. (1958). Physical phenomena in psychical research. Journal of the American Society for Psychical Research, 52, 3-23.

Edge, H. L., Morris, R. L., Palmer, J., \& Rush, J. H. (1986). Foundations of Parapsychology. Exploring the Boundaries of Human Capability. Boston, MA: Routledge \& Kegan Paul. Einstein, A. (1962). Preface. In U. Sinclair (Ed.), Mental Radio (second revised ed., pp. viii). Springfield, IL: Charles C. Thomas. First published in 1930.

Ellenberger, H. F. (1970). The Discovery of the Unconscious: The History and Evolution of Dynamic Psychiatry. New York: Basic Books.

Enz, C. P. (2002). No Time to be Brief: A Scientific Biography of Wolfgang Pauli. New York: Oxford University Press.

Feyerabend, P. (1991). It's not easy to exorcize ghosts. New Ideas in Psychology, 9, 181-186. Flew, A. (1978). Parapsychology revised: laws, miracles, and repeatability. In J. Ludwig (Ed.), Philosophy and Parapsychology (pp. 263-269). Buffalo, NY: Prometheus Books.

Flew, A. (1987). Analyzing the concepts of parapsychology. In A. Flew (Ed.), Readings in the Philosophical Problems of Parapsychology (pp. 87-106). Buffalo: Prometheus Books. 
Gauld, A. (1968). The Founders of Psychical Research. London: Routledge \& Kegan Paul.

Gauld, A. (1992). A History of Hypnotism. Cambridge: Cambridge University Press.

Gieryn, T. F. (1983). Boundary-work and the demarcation of science from non-science: Strains and interests in professional ideologies of scientists. American Sociological Review, 48, 781-795.

Grattan-Guinness, I. (1998). Letter to the editor. Journal of the Society for Psychical Research, 62, $470-471$.

Greenwood, J. A., Pratt, J. G., Rhine, J. B., Smith, B. M., \& Stuart, C. E. (1940). Extra-Sensory

Perception after Sixty Years: A Critical Appraisal of the Research in Extra-Sensory

Perception. New York: H. Holt.

Gurney, E., Myers, F. W. H., \& Podmore, F. (1886). Phantasms of the Living (2 vols.). London: Trübner.

Hacking, I. (1988). Telepathy: Origins of randomization in experimental design. Isis, 79, 427-451.

Hacking, I. (1993). Some reasons for not taking parapsychology very seriously. Dialogue, 32, $587-$ 594.

Hall, G. S. (1910). Introduction. In A. E. Tanner, Studies in Spiritism (pp. xv-xxxiii). New York: D. Appleton.

Hall, G. S. (1918). A medium in the bud. American Journal of Psychology, 29, 144-158.

Henry, J. (2002). Knowledge is Power. How Magic, the Government and an Apocalyptic Vision inspired Francis Bacon to create Modern Science. Cambridge: Icon.

Hess, D. J. (1992). Disciplining heterodoxy, circumventing discipline: parapsychology, anthropologically. In D. J. Hess \& L. Layne (Eds.), Knowledge and Society Vol. 9: The Anthropology of Science and Technology (pp. 191-222). Greenwich: JAI Press.

Hess, D. J. (1993). Science in the New Age. The Paranormal, Its Defenders and Debunkers, and American Culture. Madison: The University of Wisconsin Press.

Hodgson, R. (1900). Communication. American Journal of Psychology, 11, 436-438.

Hövelmann, G. H. (1987). "Please wait to be tolerated": Distinguishing fact from fiction on both sides of a scientific controversy. Behavioral and Brain Sciences, 10, 592-593.

Hunter, M. (2001). The Occult Laboratory. Magic, Science and Second Sight in Late SeventeenthCentury Scotland. Woodbridge: Boydell Press.

Irwin, H. J., \& Watt, C. A. (2007). An Introduction to Parapsychology (fourth ed.). Jefferson, NC: McFarland \& Company.

James, W. (1896). Address of the president before the Society for Psychical Research. Science, 3, 881-888.

James, W. (1898). Psychical research. 'A further record of observations of certain phenomena of 
trance' by Richard Hodgson. Psychological Review, 5, 420-424.

James, W. (1901). Frederic Myers's service to psychology. Proceedings of the Society for Psychical Research, 17, 13-23.

Jastrow, J. (1889). The psychology of spiritualism. Popular Science Monthly, 34, 721-732.

Jastrow, J. (1927). The animus of psychical research. In C. Murchison (Ed.), The Case for and Against Psychical Belief (pp. 281-312). London: Humphrey Milford, Oxford University Press.

Kelly, E. F., Kelly, E. W., Crabtree, A., Gauld, A., Grosso, M., \& Greyson, B. (2007). Irreducible Mind. Toward a Psychology for the 21st Century. Lanham, MD: Rowman \& Littlefield.

Kneale, M. (1950). Symposium: Is psychical research relevant to philosophy? I. Supplementary Volumes of the Proceedings of the Aristotelian Society, 24, 173-188.

Knight, D. M. (1998). Science in the Romantic Era. Aldershot: Ashgate.

Kramer, W. (2013). The first use of EEG in The Netherlands was within psychical research. Paper presented at the conference 'Psychical Research and Parapsychology in the History of Medicine and the Sciences,' University College London, 25-27 January.

Lamont, P. (2005). The First Psychic. The Peculiar Mystery of a Notorious Victorian Wizard. London: Abacus.

Le Maléfan, P., \& Sommer, A. (forthcoming). Léon Marillier and the veridical hallucination in latenineteenth and early-twentieth century French psychology and psychopathology. Submitted to History of Psychiatry.

Lugg, A. (1987). Bunkum, flim-flam and quackery: Pseudoscience as a philosophical problem. Dialectica, 41, 221-230.

Mahner, M. (2007). Demarcing science from nonscience. In T. A. F. Kuipers (Ed.), General Philosophy of Science. Focal Issues (pp. 515-575). Amsterdam: Elsevier.

Mauskopf, S. H. (Ed.). (1979). The Reception of Unconventional Science. Boulder: Westview Press.

Mauskopf, S. H., \& McVaugh, M. R. (1980). The Elusive Science. Origins of Experimental Psychical Research. Baltimore: Johns Hopkins University Press.

Maxwell, N. (1974). The rationality of scientific discovery part II: An aim oriented theory of scientific discovery. Philosophy of Science, 41, 247-295.

McClenon, J. (1984). Deviant Science: The Case of Parapsychology. Philadelphia: University of Pennsylvania Press.

Meier, C. A. (Ed.). (2001). Atom and Archetype: The Pauli/Jung Letters, 1932-1958. Princeton, NJ: Princeton University Press.

Millett, D. (2001). Hans Berger: From psychic energy to the EEG. Perspectives in Biology and 
Medicine, 44, 522-542.

Mundle, C. W. K. (1950). Symposium: Is psychical research relevant to philosophy? III.

Supplementary Volumes of the Proceedings of the Aristotelian Society, 24, 207-231.

Neurath, M., \& Cohen, R. S. (Eds.). (1973). Otto Neurath. Empiricism and Sociology. Dordrecht: Reidel.

Noakes, R. (2004a). The "bridge which is between physical and psychical research": William

Fletcher Barrett, sensitive flames, and spiritualism. History of Science, 42, 419-464.

Noakes, R. (2004b). Spiritualism, science, and the supernatural in mid-Victorian Britain. In C.

Burdett \& P. Thurschwell (Eds.), The Victorian Supernatural (pp. 23-43). Cambridge:

Cambridge University Press.

Noakes, R. (2008). The 'world of the infinitely little': connecting physical and psychical realities circa 1900. Studies in History and Philosophy of Science, 39, 323-334.

Objects of the Society. (1882). Proceedings of the Society for Psychical Research, 1, 3-6.

Ochorowicz, J. (1896). La question delà fraude dans les expériences avec Eusapia Paladino. Annales des Sciences Psychiques, 6, 79-123.

Oppenheim, J. (1985). The Other World. Spiritualism and Psychical Research in England, 18501914. Cambridge: Cambridge University Press.

Pigliucci, M., \& Boudry, M. (2013). Philosophy of Pseudoscience. Reconsidering the Demarcation Problem. Chicago: University of Chicago Press.

Pinch, T. J. (1979). Normal explanations of the paranormal: The demarcation problem and fraud in parapsychology. Social Studies of Science, 9, 329-348.

Pinch, T. J., \& Collins, H. M. (1984). Private science and public knowledge: the Committee for the Scientific Investigation of the [sic] Claims of the Paranormal and its use of the literature. Social Studies of Science, 14, 521-546.

Plas, R. (2012). Psychology and psychical research in France around the end of the 19th century. History of the Human Sciences, 25, 91-107.

Polanyi, M. (1962). Personal Knowledge. Towards a Post-Critical Philosophy (corrected ed.). London: Routledge.

Porter, R. (1999). Witchcraft and magic in Enlightenment, Romantic and liberal thought. In B. Ankarloo \& S. Clark (Eds.), Witchcraft and Magic in Europe. The Eighteenth and Nineteenth Centuries (pp. 191-282). Philadelphia: University of Pennsylvania Press.

Prince, W. F. (1930). The Enchanted Boundary. Being a Survey of Negative Reactions to Claims of Psychic Phenomena 1820-1930. Boston, MA: Boston Society for Psychic Research. Rao, K. R. (1978). Theories of psi. In S. Krippner (Ed.), Advances in Parapsychological Research 2 
(pp. 245-295). New York: Plenum.

Richet, C. (1923). Thirty Years of Psychical Research. Being a Treatise on Metapsychics (S. De Brath, Trans.). New York: Macmillan. Original French publication in 1922.

Richet, C. (1924). For and against survival. The difficulty of survival from the scientific point of view. Proceedings of the Society for Psychical Research, 34, 107-113.

Robinson, R. (1950). Symposium: Is psychical research relevant to philosophy? II. Supplementary Volumes of the Proceedings of the Aristotelian Society, 24, 189-206.

Rogosin, H. (1938). Telepathy, psychical research, and modern psychology. Philosophy of Science, $5,472-483$.

Rosenzweig, M. R., Holtzman, W. H., Sabourin, M., \& Bélanger, D. (2000). History of the International Union of Psychological Science (IUPsyS). Hove: Psychology Press/Taylor \& Francis.

Rupnow, D., Lipphardt, V., Thiel, J., \& Wessely, C. (Eds.). (2008). Pseudowissenschaft. Konzeptionen von Nichtwissenschaftlichkeit in der Wissenschaftsgeschichte. Frankfurt a.M.: Suhrkamp.

Scriven, M. (1964). The frontiers of psychology: psychoanalysis and parapsychology. In R. G. Colodny (Ed.), Frontiers of Science and Philosophy (pp. 79-129). London: George Allen \& Unwin.

Shamdasani, S. (1994). Encountering Hélène: Théodore Flournoy and the genesis of subliminal psychology. In S. Shamdasani (Ed.), Théodore Flournoy. From India to the Planet Mars: A Case of Multiple Personality with Imaginary Languages (pp. xi-li). Princeton, NJ: Princeton University Press.

Shapin, S., \& Schaffer, S. (1985). Leviathan and the Air-Pump. Hobbes, Boyle and the Experimental Life. Princeton: Princeton University Press.

Skrupskelis, I. K., \& Berkeley, E. M. (Eds.). (1992-2004). The Correspondence of William James (12 vols.). Charlottesville: University of Virginia Press.

Sommer, A. (2012a). Policing epistemic deviance: Albert von Schrenck-Notzing and Albert Moll. Medical History, 56, 255-276.

Sommer, A. (2012b). Psychical research and the origins of American psychology: Hugo Münsterberg, William James and Eusapia Palladino. History of the Human Sciences, 25, 2344.

Sommer, A. (2013a). Crossing the Boundaries of Mind and Body. Psychical Research and the Origins of Modern Psychology. Unpublished PhD thesis, University College London, London. 
Sommer, A. (2013b). Normalizing the supernormal: The formation of the "Gesellschaft für Psychologische Forschung” (“Society for Psychological Research”), c. 1886-1890. Journal of the History of the Behavioral Sciences, 49, 18-44.

Spencer-Brown, G. (1957). Probability and Scientific Inference. London: Longmann.

Stokes, D. M. (1987). Theoretical parapsychology. In S. Krippner (Ed.), Advances in Parapsychological Research 5 (pp. 77-189). Jefferson, NC: McFarland.

Taylor, E. (1983). William James on Exceptional Mental States. The 1896 Lowell Lectures. New York: Charles Scribner's Sons.

Taylor, E. (1996). William James: On Consciousness Beyond the Margin. Princeton, NJ: Princeton University Press.

Toulmin, S. (1986). The new philosophy of science and the 'paranormal'. In K. Frazier (Ed.), Science Confronts the Paranormal (pp. 13-19). Buffalo, NY: Prometheus.

Turing, A. M. (1950). Computing machinery and intelligence. Mind (New Series), 59, 433-460.

Tyndall, J. (1868). Faraday and the spiritualists. Pall Mall Gazette, May 9, Issue 1012 p. 6.

Utts, J. M. (1991). Replication and meta-analysis in parapsychology. Statistical Science, 6, 363-403.

Wallis, R. (Ed.). (1979). On the Margins of Science: The Social Construction of Rejected Knowledge (Sociological Review Monograph, vol. 27). Keele: University of Keele.

Webster, C. (1982). From Paracelsus to Newton. Magic and the Making of Modern Science. Cambridge: Cambridge University Press.

White, R. A. (1976). Surveys in Parapsychology: Reviews of the Literature, with Updated Bibliographies. Metuchen: Scarecrow Press.

White, R. A. (1990). Parapsychology: New Sources of Information, 1973-1989. Metuchen: Scarecrow Press.

White, R. A., \& Dale, L. A. (1973). Parapsychology: Sources of Information. Metuchen: Scarecrow Press.

Williams, J. P. (1984). The Making of Victorian Psychical Research: An Intellectual Elite's Approach to the Spiritual World. Unpublished PhD thesis, University of Cambridge, Cambridge.

Winter, A. (1998). Mesmerized. Powers of Mind in Victorian Britain. Chicago: University of Chicago Press.

Wolffram, H. (2006). Parapsychology on the couch: the psychology of occult belief in Germany, c. 1870-1939. Journal of the History of the Behavioral Sciences, 42, 237-260.

Wolman, B. B. (Ed.). (1977). Handbook of Parapsychology. New York: Van Nostrand Reinhold Company. 
Wundt, W. (1892). Hypnotismus und Suggestion. Leipzig: Wilhelm Engelmann.

Zusne, L., \& Jones, W. H. (1989). Anomalistic Psychology: A Study of Magical Thinking. Hillsdale, NJ: Lawrence Erlbaum Associates Inc. 